\title{
Acid and Neutral Lipases of Cultured Adipocytes of Infants and Children
}

\author{
FESTUS O. ADEBONOJO, PAUL M. COATES, ${ }^{(40)}$ AND JEAN A. CORTNER \\ The Children's Hospital of Philadelphia and The University of Pennsylvania School of Medicine, Philadelphia, \\ Pennsylvania, USA
}

\begin{abstract}
Summary
In order to determine whether the mobilization of intracellular triglycerides observed in cultured human adipocytes is associated with changes in the activities of acid and neutral lipases, the activities of both enzymes were measured weekly on cultured adipocytes for several months. The activity of acid lipase was initially very low, but rose to levels 40 times the original activity within 3 months. The activity of neutral lipase decreased rapidly within the first $2-4$ weeks and remained at approximately $25 \%$ of original levels thereafter.
\end{abstract}

\section{Speculation}

There is increasing evidence that the human adipocyte is highly specialized and that it is derived from a stromal precursor present in the adipose tissue. The cell has the capacity to acquire in culture the properties of the precursor, as evidenced by the appearance of acid lipase and disappearance of neutral lipase. We submit that the low level of acid lipase in the adipocyte is related to its lipid storage function. It remains to be proven that it is not primary to the differentiation of the adipocyte from its precursor. Furthermore, we speculate that a direct biochemical relationship exists between the neutral lipase and intracellular triglyceride stores in the adipocyte.

Although lipid mobilization from adipose tissue appears to be under the control of a number of endogenous and exogenous influences, the final step in mobilization is hydrolysis of triglycerides by lipases. Neutral lipases have been characterized in the adipose and other tissues of a number of species (4-7, 11-17, $20,21,23,27,29-33)$. They are active at neutral $\mathrm{pH}$, have affinity for long chain triglyceride esters, and sensitive to hormones such as epinephrine and insulin. Acid lipases are lysosomal in subcellular location $(13,20,32)$. First described in the liver $(13,28,32)$, acid lipases are active around $\mathrm{pH} 4.0$ and appear to have a somewhat broader chain length preference. In adipose tissue, an acid lipase, which could be stimulated by lipolytic hormones $(18,28)$ has been described as sedimenting with mitochondria $(18,28)$. This is the class of lipases deficient in the tissues of patients with lipidoses such as Wolman's disease and cholesteryl ester storage disease (8).

Earlier, we showed that human adipose cells can be sustained in culture for long periods of time $(1,2)$ and have described some of the morphologic and enzymatic properties of these cells in culture $(2)$. Other investigators $(9,24,34)$ have also established presumptive "preadipose" or adipose cells in culture. In one study (24), cultured "preadipose cells" accumulated triglycerides and incorporated glucose into lipids, thus resembling adipose cells rather than skin fibroblasts. In a recent study, Van et al. (34) found measurable levels of lipoprotein lipase activity in cultured "adipocyte precursors" of human adipose tissue. These putative "preadipose cells" were also found to possess 15 times as much triglyceride synthetase activity as skin fibroblast from the same patients and twice the fatty acid synthetase activity. Dixon-Shanies et al. (9) have found that cells cultured from adipose tissue of human adults have some metabolic characteristics which distinguish them from skin fibroblasts. We showed recently that the cultured human adipocyte is capable of mobilizing its own stored lipids over a period of weeks in culture (3). In the present study, we have attempted to determine the changes in the activities of acid and neutral lipases which accompany the mobilization of triglycerides from cultured adipocytes.

\section{MATERIALS AND METHODS}

Two to $3 \mathrm{~g}$ adipose tissue were obtained from the anterior abdominal wall of each of nine infants and children, aged 6 days to 16 years. Eight children were over 2 years of age. These children were undergoing routine operative procedures and the samples were excised at the onset of the operation. The samples were transferred to the laboratory for culture and for assay immediately after excision.

Tissues were divided into three portions of similar weight. Two portions were incubated with collagenase to isolate adipocytes, as previously described (1). The isolated adipocytes were cultured, as described previously $(1,2)$, in $25-\mathrm{ml}$ plastic flasks with $3 \mathrm{ml}$ McCoy's 5A (modified) medium (35) supplemented with $20 \%$ fetal calf serum (35). Cultures were kept at $37^{\circ}$ in $5 \% \mathrm{CO}_{2} / 95 \%$ balanced air. The initial cultures were left undisturbed for 4-7 days and the cells were fed three times weekly thereafter. The cells in each flask were transferred to a new flask weekly (25) and split every $2-3$ weeks depending on when confluence occurred. Duplicate flasks from each cell line were harvested at the times indicated in Figure 1 by methods previously described $(1,3)$; the homogenate was centrifuged at $20,000 \times g$ for $10 \mathrm{~min}$ at $4^{\circ}$ and the soluble aqueous fraction was kept on ice and assayed within $1 \mathrm{hr}$.

One of the portions of the whole tissue and a portion of the initial fresh adipocytes were each washed three times in $0.1 \mathrm{M}$ phosphate buffer, $\mathrm{pH} 7.0$, and homogenized in an equal volume of the buffer in a Teflon grinder for 1-2 min. The homogenates were centrifuged at $20,000 \times \mathrm{g}$ for $10 \mathrm{~min}$ at $4^{\circ}$. The pellets were discarded; the middle portion, called the soluble aqueous fractions, was stored on ice and assayed generally within $1 \mathrm{hr}$. However, this could be stored at $-70^{\circ}$ because both enzyme activities were stable for periods up to 1 month if thawed only once.

Acid lipase (AL) was assayed fluorometrically (8) in an Aminco-Bowman spectrophofluorometer (36) using 4-methylumbelliferyl oleate (MUO) as substrate (37) in $0.2 \mathrm{M}$ acetate

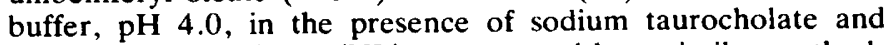
lecithin. Neutral lipase (NL) was assayed by a similar method, except that the buffer was $0.2 \mathrm{M}$ phosphate, $\mathrm{pH} 7.0$. One unit of enzyme activity was defined as $1 \mathrm{nmol}$ MUO hydrolyzed/ 
$\mathrm{min} / \mathrm{mg}$ protein. Protein was determined by the method of Lowry et al. (19). The data was analyzed by the paired Student $t$-test with statistical significance assigned only when the $P$ value was less than 0.05 . The vaiues of protein and enzyme activities were stated as the mean \pm SEM.

\section{RESULTS}

The dispersed adipocytes had a mean protein content of 4.02 $\pm 0.85 \mathrm{mg} / \mathrm{g}$ wet packed cells. The specific activity of NL in the soluble fraction of the adipocytes was $2.19 \pm 0.45$, which was not significantly different from that in the soluble fraction of the whole adipose tissue, $2.29 \pm 0.64(P>0.1)$. The specific activity of $\mathrm{AL}$ in freshly dissociated adipose cells was $0.67 \pm$ 0.19 , comparable to the value in whole adipose tissue, $0.46 \pm$ $0.13(P>0.1)$

The adipocytes in culture gradually changed shape and assumed a stellate fibroblast-like appearance. At the same time, they gradually lost their stored lipids. As shown in Figure 1, serial determinations of NL and AL in the cultured adipocytes revealed striking changes with time. The initial NL activity in the adipocytes $2.19 \pm 0.45$ decreased progressively in about 6 weeks to a level between 0.46 and 0.65 , at which it stabilized. The difference in the NL values between day 0 and day 32 is highly significant $(P<0.001)$.

By contrast, a slow but steady increase of $\mathrm{AL}$ activity in adipocyte was found during the first 4-7 weeks of culture, after which it increased more rapidly to a peak 40 times the original levels $(P<0.001)$ by 10 weeks (Fig. 1$)$.

\section{DISCUSSION}

Cultured human adipocytes are capable of mobilizing their stored triglycerides in the absence of specific stimulator of lipolysis (3). This is reflected in the release of considerable amounts of glycerol by cultured adipocytes into the culture medium (22). We (3) have found, as did Nyberg et al. (22), that intracellular triglycerides are not reduced much during the first week of culture; they are reduced considerably thereafter (3). In the current study, NL activity was seen to decline as early as 8 days of culture.

The process by which cultured adipocytes mobilize their triglycerides appears to involve a significant and simultaneous alteration in the activity of NL. The similarity in the pattern of decrease in the activity of NL in cultured adipocytes, reported

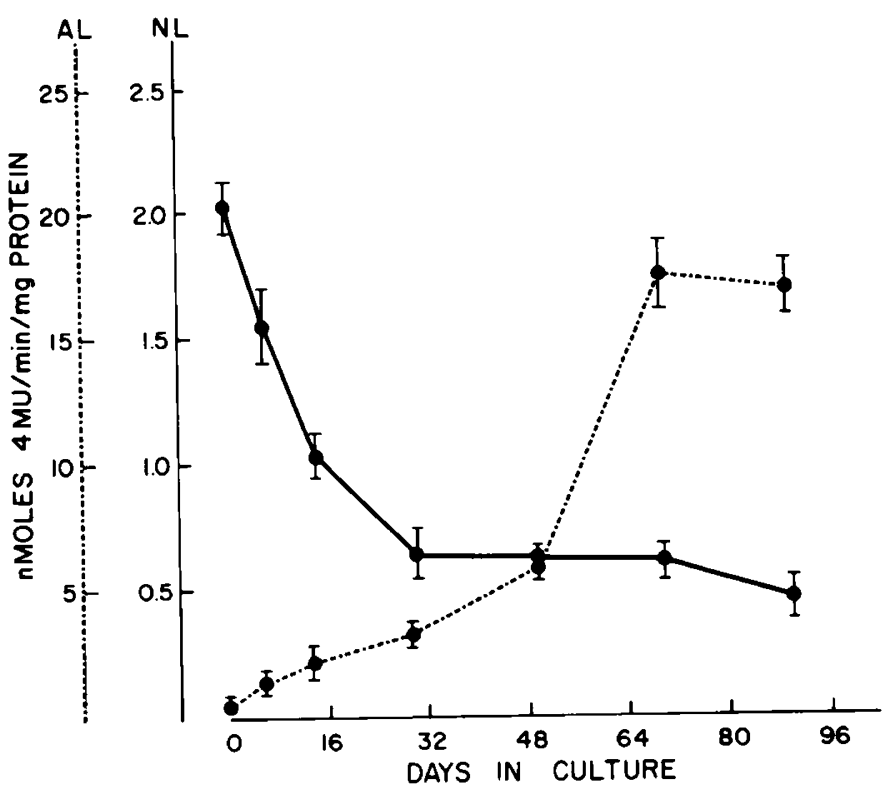

Fig. 1. Specific activities (nanomoles of $4 \mathrm{MUO}(4-\mathrm{MU}) / \mathrm{min} / \mathrm{mg}$ protein) of acid and neutral lipases (AL and NL) in the soluble fractions of cultured adipocytes of children. here, and the decrease in the intracellular triglyceride content of cultured adipocytes reported previously (3) raises the possibility that the two events are related biochemically.

The activity of AL in adipocytes is extremely low, and considerably lower than that found in normal fibroblast (8) and other nonadipose tissues $(13,20,32)$. It is even lower than that found in tissues of patients with Wolman's disease and cholesteryl ester storage disease (8), in which the deficiency of $A L$ in various nonadipose tissues has been associated with the inability of cells to clear triglycerides resulting in intralysosomal lipid accumulation.

The large increase in AL activity of adipose cell after it has been in culture for a long time suggests an adaptation which may reflect the loss of the "lipid storage" function of the cell under the culture conditions employed in this study. It is possible but unlikely that the increase in $\mathrm{AL}$ activity played a significant role in the observed lipid mobilization since most of the intracellular triglycerides had been mobilized by the time the large increase in AL activity occurred. On the other hand, as noted earlier, the decrease in NL activity of the cell occurred nearly simultaneously with the observed lipid mobilization. The fate of $A L$ and NL under lipogenic conditions may reveal more about their importance in lipid storage and mobilization in cultured adipocytes.

\section{REFERENCES AND NOTES}

1. Adebonojo, F. O.: Enzymatic adaptations by cultured adipocytes human infants and children: Effect of obese serum on the activities of lactatemalate-, and glucose-6-phosphate dehydrogenases. Pediat. Res., 9: 889 (1975).

2. Adebonojo, F. O.: Monolayer cultures of disaggregated human adipocytes. In Vitro, 11: 50 (1975).

3. Adebonojo, F. O.: Triglyceride mobilization in cultured adipocytes of human infants. Biol. Neonate, 29: (1-2): 77 (1976).

4. Angel, A., and Farkas, J.: Structural and chemical compartments in adipose cells. In: R. Levine and E. F. Pfeiffer: Adipose Tissue-Regulation and Metabolic Functions, Hormone and Metabolic Research, Suppl. 2, pp. 152-161 (Academic Press, New York, 1970).

5. Baile, Y., Gorin, E., and Shafrir, E.: Characterization of tissue lipolytic and estrolytic activities cleaving full and partial glycerides. Biochim. Biophys. Acta, 152: 28 (1968).

6. Chmelar, M., and Chmelarova, M.: Multiple forms of hormone sensitive lipase in different rat tissues. FEBS Symp., 18: 215 (1970).

7. Cooper, R. M. F., Rabouhans, M. L., and Davies, J. I.: Lipolysis in adipose tissue: Model-fitting to a nonradrenaline dose-response curve. Biochem. Soc. Trans., 2: 393 (1974).

8. Cortner, J. E., Coates, P. M., Swoboda, E., and Schnatz, J. D.: Genetic variation of lysosomal acid lipase. Pediat. Res., 10: 927 (1976).

9. Dixon-Shanies, D., Rudick, J., and Knittle, J. L.: Observations on the growth and metabolic functions of cultured cells derived from human adipose tissue. Proc. Soc. Exp. Biol. Med., 149: 541 (1975).

10. Giudicelli, H., Pastre, N., and Boyer, J.: Lipolytic activity of adipose tissue. III. The triacylglycerol lipase activity of human adipose tissue: $A$ reevaluation. Biochim. Biophys. Acta, 348: 221 (1974).

11. Giudicelli, Y., Pecquery, R., Agli, B., Jamin, C., and Quevaurilliers, J. Lipoprotein lipase and hormone sensitive lipase activities in human subcutaneous adipose tissue. Clin. Sci. Molec. Med., 50: 315 (1976).

12. Gorin, E., and Shafrir, E.: Lipolytic activity in adipose tissue homogenate toward tri-, di-, and monoglyceride substrates. Biochim. Biophys. Acta, 84: 24 (1964).

13. Guder, W., Weiss, L., and Wieland, O.: Triglyceride breakdown in rat liver: The demonstration of three different lipases. Biochim. Biophys. Acta, 187: 173 (1969).

14. Huttunen, J. K., Ellingboe, J., Pittman, R. C., and Steinberg, D.: Partial purification and characterization of hormone sensitive lipase from rat adipose tissue. Biochim. Biophys. Acta, 248: 333 (1970).

15. Khoo, J. C., Aquino, A. A., and Steinberg, D.: The mechanism of activation of hormone-sensitive lipase in human adipose tissue. J. Clin. Invest., 53: 1124 (1974).

16. Khoo, J. C., and Steinberg, D.: Reversible protein kinase activation of hormone sensitive lipase from chicken adipose tissue. J. Lipid Res., 15: 602 (1974).

17. Loeffler, G., Weinges, K. F., and Kettl, H.: Mechanismen lipolytischer vor gange in Fettgewebe. I. Vergleichende Untersuchungen uber die hormonelle Beeinflussung der Lipase und Phosphorylase in Vitro. Klin. Wschr., 44: 1085 (1966).

18. Loeffler, G., and Weiss, L.: Lipase activities in adipose tissues. In: R. Levine and E. F. Pfeiffer: Adipose Tissue-Regulation and Metabolic Functions: Hormone and Metabolic Research, Suppl. 2, pp. 32-36 (Academic Press, New York, 1964).

19. Lowry, O. H., Rosebrough, N. J., Farr, A. L., and Randall, R. J.: Protein 
measurement with the Folin phenol reagent. J. Biol. Chem., 193: 265 (1951).

20. Mahadevan, S., and Tappell, A. L.: Lysosomal lipases of rat liver and kidney. J. Biol. Chem., 243: 2849 (1968).

21. Mann, J. T., III, and Tove, S. B.: Purification and properties of a lipase from rat adipose tissue. J. Biol. Chem., 24l: 3595 (1966).

22. Nyberg, G., Mellgren, G., and Smith, U.: Human adipose tissue in culture VI. Effect of age on cell size and lipolysis. Acta Paediat. Scand., 65: 313 (1976)

23. Okuda, H., Yanagi, I., Sek, F. J., and Fujii, S.: Studies on the hormone sensitive lipase of rat epididymal adipose tissue. J. Biochem., 68: 199 (1970).

24. Poznanski, W. J., Waheed, I., and Van, R.: Human fat cell precursors Morphologic and metabolic differentiation in culture. Lab. Invest., 29: 570 (1973).

25. Puck, T. T., Ciecuira, S. J., and Fisher, H. W.: Clonal growth in vitro of human cells with fibroblasts morphology: Comparison of grnwth and general characteristics of single epithelioid and fibroblast-like cells from a variety of human organs. J. Exp. Med., 101: 148 (1959).

26. Redding, T. W., and Schally, A. V.: Effect of hypothalamic preparations on human omental adipose tissue in vitro. Metabolism, 21: 499 (1972).

27. Rizack, M. A.: An epinephrine-sensitive lipolytic activity in adipose tissue. J. Biol. Chem., 236: 657 (1961).

28. Robinson, D. S.: The clearing factor lipase activity of adipose tissue. In: Handbook of Physiology, Section 5, Adipose Tissue, p. 295 (The Williams \& Wilkins Co., Baltimore, 1965).

29. Schnatz, J. D.: Neutral and alkaline lipolytic activities in human adipose tissue. Biochim. Biophys. Acta, 116: 243 (1966).

Copyright $(1) 1978$ International Pediatric Research Foundation, Inc

$0031-3998 / 78 / 0012-0001 \$ 02.00 / 0$
30. Schnatz, J. D., Shepard, C., and Williams, R.: The hydrolysis of tissue triglyceride emulsions by homogenates of normal, adrenalin-stimulated and insulin deficient rat epididymal adipose tissue. Metabolism, 14: 122 (1965).

31. Schwartz, J. P., and Jungas, R. L., Studies on the hormone sensitive lipase of adipose tissue. J. Lipid Res., 12: 553 (1971)

32. Stoffel, W., and Greten, H.: Studies on lipolytic activities of rat liver lysosomes. Hoppe Seyler's Z. Physiol. Chem., 348: 1145 (1967).

33. Strand, O., Vaughn, M., and Steinberg, D.: Rat adipose tissue lipases: Hormone sensitive lipase activity against triglycerides compared with activity against lower triglycerides. J. Lipid Res., 5: 554 (1964).

34. Van, R. L. R., Bayliss, C. E., and Roncari, A. K.: Cytological and enzymological characterization of adult human adipocyte precursors in culture. J. Clin. Invest., 58: 699 (1976).

35. Flow Laboratories, Rockville, MD 20852.

36. American Instrument Co., Silver Spring, MD 20910

37. Research Products Int., Elk Grove Village, IL 60005.

38. We thank Ms. Joanne Werntz for valuable technical assistance and Drs. William Mellman and Alfred $M$. Bongiovanni for reviewing the manuscript. We also thank the surgeons and the operating room nursing staff of the Children's Hospital of Philadelphia for their cooperation in obtaining the adipose tissue specimens.

39. This work was supported by General Research Support Grant GRS 5-S-01RR05506-13, NIH, and Human Genetic Center Grant GM-20138.

40. Requests for reprints should be addressed to: Paul M. Coates, M.D. The Children's Hospital of Philadelphia, 34th and Civic Center Boulevard, Philadelphia, Pennsylvania 19104 (USA).

41. Received for publication December 13,1976.

42. Accepted for publication April 26, 1977.

Printed in U.S.A.

Pediat. Res. 12: 29-34 (1978)

Lead

metabolic balance studies

\title{
Absorption and Retention of Lead by Infants
}

\author{
EKHARD E. ZIEGLER, ${ }^{(21)}$ BARBARA B. EDWARDS, ROBERT L. JENSEN, KATHRYN R. \\ MAHAFFEY, AND SAMUEL J. FOMON \\ Department of Pediatrics, University of lowa, lowa City, Iowa, USA
}

\section{Summary}

Eighty-nine metabolic balance studies were performed with 12 normal infants ranging in age from 14-746 days. Intake and fecal and urinary excretions of lead were determined and net absorption and net retention were calculated. Subjects were fed milk or formula and commercially prepared strained foods. Intakes of lead ranged from $0.83-22.61 \mu \mathrm{g} / \mathrm{kg} /$ day with a mean of $9.43 \mu \mathrm{g} / \mathrm{kg} /$ day. Urinary excretion averaged 1.02 (SD 0.68) $\mu \mathrm{g} / \mathrm{kg} /$ day and was positively correlated with lead intake (Fig. 1). Fecal excretion was highly correlated with intake of lead (Fig. 2); fecal excretion exceeded intake in 10 studies. In 61 balance studies with lead intakes greater than $5 \mu \mathrm{g} / \mathrm{kg} / \mathrm{day}$, net absorption averaged $41.5 \%$ of lead intake and net retention averaged $31.7 \%$ of intake.

Retention of lead was highly correlated with lead intake (Fig. 3). Urinary plus fecal excretion of lead exceeded intake in 19 of 28 balances in which lead intakes were less than $5 \mu \mathrm{g} / \mathrm{kg} / \mathrm{day}$. Absorption and retention of lead were inversely correlated with intake of calcium (Fig. 4). Absorption and retention of lead accounted for greater percentages of intake of lead in this study of infants and young children than have been reported in studies of older subjects.

\section{Speculation}

Highly efficient absorption and retention of ingested lead by young children may be partly responsible for the high prevalence of lead intoxication in this age group.

In 1971 an ad hoc committee of the Bureau of Community Environmental Management, PHS (9) suggested $300 \mu \mathrm{g} /$ day for children as the daily permissible intake of lead from all sources. Children 1-3 years of age were specifically included. The daily permissible intake was based, in part, on the assumption that $90 \%$ of ingested lead would be excreted - an assumption based on extrapolation from data concerning adults.

However, it is known that suckling rats absorb a greater percentage of ingested lead than do older rats $(6,10)$. In addition, Alexander et al. (1) have reported data from 11 metabolic balance studies with subjects less than 8 years of age, including six studies with three subjects less than 2 years of age. As estimated from the figures included in the publication, these studies indicated that considerably less than $90 \%$ of ingested lead was excreted. 